\title{
Jak dzieci/młodzież z głębszą niepełnosprawnością intelektualną kodują formacje słowotwórcze (na przykładzie kategorii nazw narzędzi)
}

\begin{abstract}
Renata Marciniak-Firadza, Jak dzieci/młodzież z głębszą niepetnosprawnościa intelektualna koduja formacje stowotwórcze (na przykładzie kategorii nazw narzędzi) [How children / young people with deeper intellectual coding disability manage words formation (on the example of the category of the tool names)]. Interdyscyplinarne Konteksty Pedagogiki Specjalnej, nr 22, Poznań 2018. Pp. 219-238. Adam Mickiewicz University Press. ISSN 2300-391X. DOI: https:// doi.org/10.14746/ikps.2018.22.13

Word formation plays an important role in the child's linguistic and cognitive development, because the ability to interpret word formation forms and actively use the knowledge of derivation rules are the most important manifestations of language competence at the lexical level. The aim of the article is the linguistic interpretation of selected names of tools obtained from children and adolescents aged 6-19 with diagnosed intellectual disabilities in a moderate and significant degree. Article pays attention first of all to the existence of word-formation structures in the linguistic awareness of children / adolescents and to the fact whether newly formed words are created in accordance with existing word-formation patterns existing in the Polish language or whether they diverge from these patterns.
\end{abstract}

KEY WORDS: word formation, tool names, word formation skills, moderate and significant intellectual disability 


\section{Wstęp}

Słowotwórstwo odgrywa istotną rolę $\mathrm{w}$ rozwoju językowym i poznawczym dziecka ${ }^{1}$. Słowa bardzo wcześnie zaczynają pośredniczyć w odzwierciedlaniu przez dziecko otaczającego świata i wywierają decydujący wpływ na rozwój jego procesów poznawczych. Dziecko już od najwcześniejszych chwil życia dąży do zrozumienia świata: zadaje pytania, chce wiedzieć, poszukuje adekwatnych nazw. Nominowanie jest bardzo ważne, gdyż dziecko dopiero wtedy naprawdę poznało osoby, rzeczy, przedmioty, gdy wyodrębniło je osobną nazwą. Dopóki desygnat nie ma nazwy w osobowym języku dziecka, pozostaje niezidentyfikowaną częścią rzeczywistości pozajęzykowej². Jak pisze Amelia Dziurda-Multan: „W języku osobowym dziecko odnosi się do rzeczywistości, nazywa ją i ujawnia swój stosunek do niej. Każdy przedmiot, osobę, rzecz, zjawisko oznacza odpowiednią nazwą"3. Ida Kurcz natomiast konstatuje, iż system poznawczy ludzi kategoryzuje świat, pozwala wyodrębnić w nim zbiory realnych przedmiotów i zjawisk, tworzyć kategorie. Szczególną grupę stanowią kategorie ontologiczne, służące systematyzowaniu i interpretowaniu obrazu świata, np. kategorie rzeczy, ruchu, miejsca, czynności, zdarzenia, stanu, ilości, sposobu, właściwości, czasu, przyczyny, Boga i osoby ludzkiej. Proces kategoryzacji to proces tworzenia się systemu pojęć w umyśle małego dziecka ${ }^{4}$.

Jak poświadczają najważniejsze teorie słowotwórcze, np. teoria dwuczłonowości Jana Rozwadowskiego ${ }^{5}$, teoria logiczno-syntak-

${ }^{1}$ E. Muzyka-Furtak, Kwestionariusz stowotwórczy w ocenie kompetencji językowej dzieci z zaburzeniem stuchu, [w:] Metody i narzędzia diagnostyczne w logopedii, red. M. Kurowska, E. Wolańska, Dom Wydawniczy Elipsa, Warszawa 2015, s. 251.

2 A. Dziurda-Multan, Dziecięce sposoby tworzenia nazw, Wydawnictwo Katolickiego Uniwersytetu Lubelskiego, Lublin 2008, s. 19, 155.

${ }^{3}$ Ibidem, s. 7.

${ }^{4}$ I. Kurcz, Jezyk a psychologia, WSiP, Warszawa 1992, s. 223-225; I. Kurcz, Psychologia języka i komunikacji, Wydawnictwo Naukowe "Scholar" Warszawa 2000, s. $160-161,167$.

${ }^{5}$ J. Rozwadowski, O zjawiskach i rozwoju języka. 9. O dwuczłonowości wyrazów, „Język Polski" 1921, z. 6, s. 129-139. 
tyczna Witolda Doroszewskiego ${ }^{6}$, teoria Milosza Dokulila ${ }^{7}$ czy teoria kognitywna ${ }^{8}$, język buduje $\mathrm{w}$ umysłach ludzkich obraz świata, a stanowiąc układ społecznych kategorii, ujednolica poznanie ${ }^{9}$. Na poziomie słowotwórczym języka w wyrazisty sposób uwidacznia się więc związek pomiędzy procesami poznawczymi i językowymi.

\section{Percepcja i nazywanie świata oraz jego elementów przez dzieci/młodzież z niepełnosprawnością intelektualną}

Nabywanie kompetencji językowej przez dziecko nie jest procesem łatwym, zwłaszcza w zakresie języka polskiego, cechującego się bogactwem form wyrazowych oraz złożonością zasad budowy wyrazów i zdań.

Intensywny rozwój słownictwa, jak i struktur gramatycznych, związany z rozwojem procesów poznawczych dziecka: pamięci, spostrzeżenia i uwagi, obserwuje się u dzieci o typowym rozwoju $\mathrm{w}$ wieku przedszkolnym ${ }^{10}$, wtedy to bowiem dziecko przyswaja od swojego otoczenia system językowy, czyli określony zasób leksykalny oraz podstawy gramatyki ${ }^{11}$.

${ }^{6}$ W. Doroszewski, Kategorie stowotwórcze, "Sprawozdania z posiedzeń Towarzystwa Naukowego Warszawskiego", Wydz. I, 1946, t. XXXIX, s. 18-39.

${ }^{7}$ M. Dokulil, Teoria derywacji, tłum. A. Bluszcz, J. Stachanowski, Ossolineum, Wrocław 1979.

${ }^{8}$ R. Grzegorczykowa, B.Szymanek, Kategorie słowotwórcze w perspektywie kognitywnej, [w:] Wspótczesny język polski, red. J. Bartmiński, Wydawnictwo Uniwersytetu Marii Curie-Skłodowskiej, Lublin 2001, s. 469-484.

${ }^{9}$ S. Grabias, Jezyk, poznanie, interakcja, [w:] Jezyk. Interakcja. Zaburzenia mowy. Metodologia badań, red. T. Woźniak, A. Domagała, Wydawnictwo Uniwersytetu Marii Curie-Skłodowskiej, Lublin 2007, s. 376.

${ }^{10} \mathrm{~W}$ literaturze przedmiotu podaje się, że dziecko w drugim roku życia odkrywa, że każda rzecz ma swoją nazwę (por. Aitchison 2002, s. 128; Stawinoga 2007, s. 65).

${ }^{11} \mathrm{H}$. Borowiec, Kategorie interpretowania rzeczywistości w języku dzieci, [w:] Jezzyk-interakcja - zaburzenia mowy. Metodologia badań, red. T. Woźniak, A. Domagała, Wydawnictwo Uniwersytetu Marii Curie-Skłodowskiej, Lublin 2007, s. 107; por. też M. Zarębina, Kształtowanie się systemu językowego dziecka, Ossolineum, Wrocław 1965; M. Zarębina, Język polski w rozwoju jednostki. Analiza tekstów dzieci do wieku szkolnego. Rozwój seman- 
Eksplozja nazywania - pragnienie, by nazywać wszystko dokoła, polega na etykietowaniu tego, co znajduje się w zasięgu wzroku i prowadzi do uświadomienia sobie przez dziecko faktu, że słowa są symbolami, które odnoszą się do rzeczy. W dalszej kolejności następuje rozszerzenie etykiety na inne egzemplarze tego samego rodzaju12. Postrzegane przedmioty najpierw jako całość (lub zbiór cech) zaliczane są do określonej klasy pojęciowej i w ten sposób dochodzi do przyporządkowania nowych zjawisk do ogólnej klasy pojęć znanych wcześniej, a następnie, na podstawie cechy odróżniającej, są spośród innych podobnych egzemplarzy te klasy wyodrębniane ${ }^{13}$.

Rozwoju słowotwórczego nie można rozpatrywać w izolacji od kształtowania się słownika. Spoglądając na zjawiska słowotwórcze z tej perspektywy, należy najpierw postawić pytanie: co dzieci muszą zrobić, żeby nauczyć się słów danego języka?

Po pierwsze - jak podkreśla Ewa Muzyka - muszą nauczyć się izolować słowa w strumieniu mowy, wydzielać części słów oraz identyfikować tematy, końcówki fleksyjne i afiksy. Po drugie, muszą nauczyć się rozpoznawać potencjalne znaczenia poszczególnych elementów, sięgając do różnych kategorii ontologicznych, ustanowionych do reprezentowania i porządkowania otaczającego świata - kategorii obiektów, czynności, relacji, własności. Po trzecie, muszą nauczyć się odwzorowywania potencjalnych znaczeń w zidentyfikowane formy wyrazowe ${ }^{14}$.

Aby dziecko mogło prawidłowo rozpoznawać, określać czy tworzyć morfemową strukturę wyrazów, powinno mieć ukształtowane wyobrażenie o ich kategorialnym znaczeniu, umieć dostrze-

tyczny języka dziecka, Wydawnictwo Naukowe WSP, Kraków 1980; L. Kaczmarek, Nasze dziecko uczy się mowy, Wydawnictwo Lubelskie, Lublin 1966; M. Chmura-Klekotowa, Neologizmy stowotwórcze w mowie dzieci, „Prace Filologiczne” 1971, nr 21, s. 99-235; M. Mnich, Sprawność językowa dzieci w wieku wczesnoszkolnym, Oficyna Wydawnicza „Impuls”, Kraków 2002.

12 R. Stawinoga, Twórczość językowa dziecka w teorii i praktyce edukacyjnej, Wydawnictwo Uniwersytetu Marii Curie-Skłodowskiej, Lublin 2007, s. 65.

${ }^{13}$ E. Muzyka-Furtak, Twórczość wyrazowa dzieci 7-letnich, „Logopedia” 2011, t. $39 / 40$, s. 57 .

14 E. Muzyka, Sposoby interpretowania konstrukcji słowotwórczych przez dzieci niestyszace, "Logopedia” 2007, t. 36, s. 98. 
gać różnice wyrażane afiksem i różnicować leksykalnie (owoc owocowy - owocny), rozumieć derywację z wymianą fonetyczną (róg-rożek), rozpoznawać kategorie gramatyczne wyrazów i ich integrację w całokształt znaczenia ${ }^{15}$.

Stopniowo poszczególne zakresy tematyczne poszerzane są o nowe słowa, które rozbudowują sieć powiązań semantycznych ${ }^{16}$.

Zdaniem autorki ogólne kierunki nabywania słownictwa przez dzieci można ująć następująco:

- najpierw rozumienie, potem produkcja,

- najpierw słowa treściowe, potem funkcyjne,

- najpierw konkretne, potem abstrakcyjne,

- najpierw powiązane sytuacyjnie, potem oderwane,

- najpierw rzeczowniki, potem czasowniki, zaimki, przymiotniki, przysłówki, a na końcu przyimki i spójniki,

- najpierw pojęcia z poziomu podstawowego, potem z poziomu podrzędnego i nadrzędnego,

- najpierw znaczenia rozmyte (rozszerzone/zawężone), potem sprecyzowane,

- najpierw słowa bezfleksyjne, potem nacechowane gramatycznie ${ }^{17}$. Rozwój słownictwa splata się z rozwojem umiejętności gramatycznych, których podstawy bardzo wcześnie dzieci polskojęzyczne opanowują ${ }^{18}$.

Istnieją dowody na to, jak pisze Wątorek, że nawet małe dzieci analizują wewnętrzną strukturę wyrazów, wydzielając w nich morfemy. Jednym z dowodów jest zdolność trzy-, czterolatków do generowania własnych słów, czyli tzw. neologizmów dziecięcych. Wzorując się na znanych sobie wyrazach, poprzez liczne analogie dzieci tworzą nowe, potrzebne im do komunikacji w danym momencie nazwy ${ }^{19}$.

15 A. Giermakowska, Ocena kompetencji stowotwórczej uczniów z trudnościami w czytaniu i pisaniu na poziomie edukacji wczesnoszkolnej, „Szkoła Specjalna” 2012, z. 5, s. 357.

16 A. Wątorek, Kompetencja językowa uczniów z lekką niepetnosprawnością intelektualna, Nomos, Kraków 2014, s. 17.

17 Ibidem, s. 16-17.

18 E. Łuczyński, Fleksja języka polskiego z punktu widzenia ontogenezy mowy, „Biuletyn Polskiego Towarzystwa Językoznawczego" 2002, t. 58, s. 158.

19 A. Wątorek, op. cit., s. 17. 
W ujęciu kognitywnym istotne dla rozwoju komunikacji językowej są zdolności rozróżniania. Speck podkreśla, że dziecko powinno nauczyć się dokonywania czterech form rozróżnień, a więc musi:

1. Zrozumieć, że symbol (słowo) odnosi się do określonego obiektu lub że go reprezentuje, na przykład przedmiot lub czynność.

2. Rozróżniać rozmaite uwarunkowania w danym środowisku, które różnią się od siebie i które ulegają identyfikacji i kategoryzacji poprzez własny system językowy, czyli rozróżniać rzeczy i procesy.

3. Odróżniać rozmaite symbole językowe; chodzi o właściwe odróżnianie od siebie podobnie brzmiących symboli, np. shift 'ołówek' i shiff 'statek', jak również dostrzeżenie fundamentalnych różnic, na przykład między krowa a nożyczkami.

4. Dokonywać rozróżnień pomiędzy odmienną kolejnością symboli, to jest odmiennymi szykami wyrazów w zdaniu. Nie jest to bez znaczenia, czy powiemy "drzwi są zamknięte” albo "czy drzwi są zamknięte" lub też: "Marek prowadzi Anię” albo „Ania prowadzi Marka”20.

Powyższe uwagi dotyczą dzieci o typowym rozwoju. Nieco inaczej percepcja i nazywanie świata oraz jego elementów wygląda u dzieci z niepełnosprawnością intelektualną.

W literaturze przedmiotu zwraca się uwagę na fakt, że niepełnosprawność intelektualna to nie tylko „opóźnienie rozwoju, lecz inna jakość rozwoju" 21, na nieharmonijność tego rozwoju, na zupełnie inne doświadczenia życiowe dzieci z tą dysfunkcją22, na fakt, że

${ }^{20}$ K. Kaczorowska-Bray, Kompetencja i sprawność językowa dzieci z niepetnosprawnościq intelektualna w stopniu znacznym, umiarkowanym i lekkim, Wydawnictwo Uniwersytetu Gdańskiego, Gdańsk 2017, s. 104.

${ }^{21} \mathrm{H}$. Nartowska, Opóźnienia i dysharmonie rozwoju dziecka, WSiP, Warszawa 1980, s. 106.

22 J. Kostrzewski, Różnice profilu inteligencji, niektórych uzdolnień oraz w cechach motoryczności dzieci umystowo upośledzonych i normalnych, [w:] Z zagadnień psychologii dziecka umysłowo upośledzonego. Materiaty pomocnicze do psychologii upośledzonych umysłowo, red. J. Kostrzewski, t. 1, Wydawnictwo WSPS im. M. Grzegorzewskiej, 
„opóźnione w rozwoju i zaburzone w największym stopniu są czynności o najwyższej organizacji, czyli te, które najpóźniej kształtowały się w filogenezie i ontogenezie, czyli przede wszystkim myślenie i mowa"23, wreszcie, że słownik, którym się te dzieci posługują, jest ubogi, długo utrzymują się agramatyzmy, notowane są rozmaite rodzaje wad wymowy ${ }^{24}$.

Zaburzenia wyznaczników podmiotowych (indywidualnych) nabywania i użycia języka, a więc poznawczych, motywacyjnych i emocjonalnych, są niejako - jak pisze Kaczorowska-Bray - wpisane w definicje upośledzenia umysłowego ${ }^{25}$.

W literaturze z jednej strony podkreśla się, że u dzieci z niepełnosprawnością intelektualną w stopniu umiarkowanym zdolność do rozumienia rzeczywistości i formułowania o niej wniosków jest znacznie ograniczona ${ }^{26}$, z drugiej, że potrafią one nadać przedmiotom znaczenie, mają możliwość oderwania się w myśleniu od danych aktualnego spostrzegania, zaczynają uwzględniać różne aspekty (np. długość, wysokość, barwę), jak też wzajemne stosunki między cechami przedmiotów, choć zdolność do wyodrębniania istotnych szczegółów, cech zjawisk i przedmiotów jest znacznie ograniczo-

Warszawa 1978; J. Kostrzewski, Podstawy współczesnej diagnostyki psychologicznoklinicznej niedorozwoju umysłowego u dzieci, red. J. Kostrzewski, Z zagadnień psychologii dziecka umystowo upośledzonego. Materiaty pomocnicze do psychologii upośledzonych umysłowo, t. 1, Wydawnictwo WSPS im. M. Grzegorzewskiej, Warszawa 1978.

${ }^{23} \mathrm{H}$. Nartowska, Opóźnienia $i$ dysharmonie rozwoju dziecka, WSiP, Warszawa 1980, s. 102.

${ }_{24}$ M. Bogdanowicz, Psychologia kliniczna dziecka w wieku przedszkolnym, WSiP, Warszawa 1985, s. 88-89.

${ }^{25}$ K. Kaczorowska-Bray, Zaburzenia komunikacji językowej w grupie osób z niepetnosprawnościa intelektualna, [w:] Diagnoza i terapia logopedyczna osób z niepetnosprawnością intelektualną, red. J.J. Błeszyński, K. Kaczorowska-Bray, Harmonia Universalis, Gdańsk 2012, s. 42.

${ }^{26}$ J. Kostrzewski, Charakterystyka osób upośledzonych umysłowo, [w:] Upośledzenie umystowe - Pedagogika, red. K. Kirejczyk, PWN, Warszawa 1981; M. Bogdanowicz, op. cit.; R. Kościelak, Psychologiczne podstawy rewalidacji upośledzonych umystowo, PWN, Warszawa 1989; L. Cierpiałkowska, Psychopatologia, Wydawnictwo Naukowe Scholar, Warszawa 2007. 
na ${ }^{27}$. Można też $u$ nich zaobserwować początki rozumienia relacji części do całości, stosunku zachodzącego między pojęciem nadrzędnym a podrzędnym ${ }^{28}$. Dzieci z niepełnosprawnością intelektualną $\mathrm{w}$ stopniu umiarkowanym mają też poważne problemy w zapamiętywaniu, przechowywaniu, rozpoznawaniu i odtwarzaniu informacji ${ }^{29}$.

Dzieci z niepełnosprawnością intelektualną $\mathrm{w}$ stopniu znacznym stanowią, jak zauważa Lidia Cierpiałkowska ${ }^{30}$, grupę podobną do umiarkowanego stopnia niepełnosprawności intelektualnej pod względem zarówno obrazu klinicznego, jak i genezy, patomechanizmu oraz współwystępujących zaburzeń neurologicznych i psychicznych. Jednakże poziom sprawności wszystkich funkcji intelektualnych jest niższy. Myślenie pojęciowo-słowne jest głęboko upośledzone ${ }^{31}$.

Nieprawidłowy przebieg rozwoju mowy i wadliwie kształtujące się mechanizmy jej funkcjonowania powodują to, że nie spełnia ona w sposób właściwy swej roli „jako czynnik wspomagający odbiór nazywanych zjawisk i jako czynnik uogólniania (pojęcia), które jest motorem wszelkich dostosowań (nowych) otrzymanych informacji do dawnych, tkwiących $w$ "depozycie" pamięciowym, uporządkowanych w modele określone słowami" 32 .

27 J. Głodkowska, Pomóżmy dziecku z upośledzeniem umysłowym doświadczać przestrzeni. Orientacja przestrzenna w teorii, diagnozie i rozwoju dziecka, WSPS, Warszawa 2000, s. 66; L. Cierpiałkowska, op. cit.

28 Za: E. Kudłacik, Poziom funkcjonowania dzieci głębiej upośledzonych umysłowo w wieku przedszkolnym w zakresie porozumiewania się oraz umiejętności stuchowo językowych $i$ wzrokowoprzestrzennych, (w:) E. Minczakiewicz (red.), Komunikacja - mowa język w diagnozie $i$ terapii zaburzeń rozwoju u dzieci i młodzieży niepełnosprawnej, Wydawnictwo Naukowe AP, Kraków 2002, s. 40-69.

29 J. Kostrzewski, op. cit.; M. Bogdanowicz, op. cit.; R. Kościelak, op. cit.; L. Cierpiałkowska, op. cit.

${ }^{30}$ L. Cierpiałkowska, op. cit., s. 178.

31 E. Kudłacik, op. cit., s. 41.

32 Z. Tarkowski, Mowa osób upośledzonych umysłowo i jej zaburzenia, [w:] Podstawy neurologopedii. Podręcznik akademicki, red. T. Galkowski, E. Szeląg, G. Jastrzębowska, Uniwersytet Opolski, Opole 2005, s. 588. 
Zakłócenia komunikacji językowej, uwidaczniające się na każdej płaszczyźnie opisu języka (fonologii, morfologii, składni, semantyki i pragmatyki), zubażają proces wyrażania znaczeń, ujmowania myśli i docierania do rzeczywistości (kultury) ${ }^{33}$.

Dzieci z niepełnosprawnością intelektualną opisywane są zazwyczaj jako preferujące $\mathrm{w}$ swoim zasobie słownikowym słownictwo konkretne ${ }^{34}$.

Badacze są zgodni co do tego, że przyswajanie sobie słownictwa konkretnego i relacji semantycznych odbywa się u dzieci z niepełnosprawnością intelektualną i u dzieci w normie w taki sam sposób, choć $\mathrm{u}$ tych pierwszych $\mathrm{w}$ zdecydowanie wolniejszym tempie. Przewaga słownictwa o znaczeniu konkretnym zwiększa się wraz z głębokością niepełnosprawności i5.

Badania prowadzone przez Tadeusza Gałkowskiego ${ }^{36}$ pozwoliły na ocenę stanu rozwoju słownika biernego i czynnego w zakresie jedenastu kategorii (przedmioty użytku codziennego, części ciała, zwierzęta i ptaki, zabawki, warzywa i owoce, pojazdy, części ubrania, osoby, wielkości, kształty, kolory) w grupie dzieci z niepełnosprawnością w stopniu znacznym. Uzyskane wyniki badań potwierdziły, że w obu słownikach przeważało słownictwo konkretne, użyteczne dla dzieci $w$ wielu sytuacjach życiowych. Najwyższe rangi uzyskały nazwy przedmiotów codziennego użytku, części ciała, nazwy oznaczające zwierzęta i ptaki, zabawki.

Słownictwo stosowane przez dzieci $\mathrm{z}$ niepełnosprawnością w stopniu umiarkowanym i znacznym ma często inny zakres znaczeniowy niż słownikowy: niewielka liczba słów wchodzących do

${ }^{33}$ M. Michalik, Kompetencja składniowa w normie i zaburzeniach. Ujęcie integrujace, Wydawnictwo Naukowe Uniwersytetu Pedagogicznego, Kraków 2011, s. 178.

34 M.R. Griffer, Language and children with intellectual disorders, [w:] An introduction to children with language disorders, red. V.A. Reed, M.A. Pearson, wyd. IV, Boston 2012; J.J. Błeszyński, Niepetnosprawność intelektualna. Mowa - język - komunikacja. Czy iloraz inteligencji wyjaśnia wszystko?, Harmonia Universalis, Gdańsk 2013.

35 M. R. Griffer, op. cit., s. 250-251.

36 T. Gałkowski, Dzieci specjalnej troski. Psychologiczne podstawy rehabilitacji dzieci opóźnionych umysłowo, Wiedza Powszechna, Warszawa 1979, s. 194-195. 
ich zasobu leksykalnego musi służyć dziecku w wielu sytuacjach, stąd też obecność swoistych "słów wytrychów". Co prawda użycie wyrazu $\mathrm{w}$ znaczeniu szerszym niż znaczenie słownikowe pojawia się u wszystkich dzieci, jednak w wypadku dzieci z niepełnosprawnością intelektualną dotyczy ono znaczącej części zasobu słownikowego ${ }^{37}$.

\section{Kodowanie formacji słowotwórczych przez dzieci/młodzież z głębszą niepełnosprawnością intelektualną - zagadnienia metodologiczne}

\section{A. Cel artykułu}

Celem artykułu jest interpretacja lingwistyczna wybranych nazw narzędzi uzyskanych $\mathrm{w}$ wyniku badań pilotażowych $\mathrm{w}$ jednym z ośrodków rehabilitacyjno-edukacyjno-wychowawczym w województwie łódzkim. Badania pilotażowe mają dać odpowiedź na pytanie, czy obejmować badaniami dotyczącymi akwizycji reguł słowotwórczych dzieci/młodzież z głębszą niepełnosprawnością intelektualną.

W artykule pragnę zwrócić uwagę przede wszystkim: a) na sposób istnienia konstrukcji słowotwórczych w świadomości językowej badanych; b) na fakt, czy nowo powstałe wyrazy utworzone są zgodnie z istniejącymi w języku polskim wzorcami słowotwórczymi, czy też od tych wzorców odbiegają.

\section{B. Grupa badawcza}

Grupę badawczą stanowią dzieci i młodzież w wieku od 6 do 19 lat ze zdiagnozowaną niepełnosprawnością intelektualną $\mathrm{w}$ stopniu umiarkowanym i znacznym wraz z niepełnosprawnościami sprzężonymi. Osoby te nie mogą realizować obowiązku szkolnego w szkołach publicznych. Na 39 dzieci uczęszczających

${ }^{37}$ K. Kaczorowska-Bray, op. cit., s. 137. 
do ośrodka, wywodzących się $\mathrm{z}$ podobnych środowisk, tylko 8 (6 $\mathrm{z}$ niepełnosprawnością $\mathrm{w}$ stopniu umiarkowanym i dwoje w znacznym) spełnia warunek badań, tj. komunikuje się werbalnie z otoczeniem. Na etapie badań pilotażowych jako mało istotne potraktowano dane dotyczące płci badanych. Przyjęto również (celowo) tak duży przedział wiekowy, kryterium było tu realizowanie obowiązku szkolnego.

\section{Procedura badawcza}

W badaniach dotyczących przyswajania reguł słowotwórczych $\mathrm{w}$ procesie akwizycji języka należy zwrócić uwagę m.in. na ocenę rozumienia (recepcji, dekodowania, interpretowania) i tworzenia (ekspresji, kodowania) konstrukcji słowotwórczych.

Umiejętność rozumienia i tworzenia konstrukcji słowotwórczych za Ewą Muzyką-Furtak traktuję następująco:

- rozumienie jest formalno-semantyczną analizą konstrukcji, dekodowaniem znaczeń elementów składowych formacji, jest interpretowaniem konstrukcji słowotwórczych, zgodnym z ustaleniami społecznymi i własnym doświadczeniem;

- tworzenie jest formalno-semantyczną syntezą cech składających się na znaczenie konstrukcji, jest kodowaniem znaczeń w konstrukcję słowotwórczą, jest produkowaniem, polegającym na przywołaniu z własnego zasobu leksykalnego określonych jednostek formalnie i semantycznie powiązanych $\mathrm{z}$ wyznaczonym zestawem cech semantycznych ${ }^{38}$.

Źródłem gromadzonych przeze mnie informacji na temat kompetencji słowotwórczych dzieci są $\mathrm{w}$ tym przypadku próby eksperymentalne, polegające na zadawaniu w sprzyjających dziecku warunkach odpowiednio sformułowanych pytań $\mathrm{w}$ celu wydobycia określonej formy wyrazowej.

W kwestii zakresu badań, eksploracją i analizami objęte zostały dwa rodzaje umiejętności świadczących o poziomie opanowania

38 E. Muzyka-Furtak, Konstrukcje słowotwórcze w świadomości językowej dzieci niestyszacych, Wydawnictwo Uniwersytetu Marii Curie-Skłodowskiej, Lublin 2010, s. 80. 
reguł słowotwórczych, tj. umiejętności rozumienia (dekodowania, interpretowania, recepcji) i tworzenia (kodowania, ekspresji) wyrazów pochodnych.

W artykule ograniczyłam się do omówienia umiejętności kodowania nazw należących do jednej wybranej kategorii słowotwórczej, tj. kategorii nazw narzędzi - zgodnie z klasyfikacją Renaty Grzegorczykowej39. W kwestionariuszu zamieściłam 25 pytań o nazwy narzędzi. W kwestii zasady doboru materiału badawczego - zastosowalam przede wszystkim kryterium dystrybucyjne.

Jeśli chodzi o kodowanie, to kwestionariusz sprawdzał umiejętność utworzenia nazwy na podstawie parafrazy słowotwórczej lub, w przypadku trudności, umiejętność tworzenia na podstawie zestawu cech semantycznych wyeksplikowanych ze znaczenia strukturalnego formacji ${ }^{40}$. Pomocniczo wykorzystany był też kwestionariusz obrazkowy.

Kwestionariusz był wypełniany indywidualnie z każdym dzieckiem. Każde dziecko były poinstruowane, jak będzie wyglądał przebieg badania, czego się od dziecka oczekuje. Każde zostało też zapoznane z przykładowymi odpowiedziami.

\section{Kodowanie formacji słowotwórczych przez dzieci/młodzież z głębszą niepełnosprawnością intelektualną - wnioski z badań}

Język wyraża uczucia, obserwacje i związane z rzeczywistością myśli małego człowieka ${ }^{41}$. Jak podkreśla Stefan Szuman, myśli dziecka są procesami, w obrębie których nie tylko nazywa ono przedmiot odpowiednią nazwą, lecz są procesami, w których mały

${ }^{39}$ R. Grzegorczykowa, Zarys stowotwórstwa polskiego. Stowotwórstwo opisowe, PWN, Warszawa 1982.

40 E. Muzyka-Furtak, op. cit., s. 81.

41 A. Dziurda-Multan, Dziecięce sposoby tworzenia nazw, Wydawnictwo Katolickiego Uniwersytetu Lubelskiego, Lublin 2008, s. 89. 
człowiek coś twierdzi o cechach przedmiotu, relacjach, w jakie on może wchodzić z innymi przedmiotami, o czynnościach, jakie dany przedmiot wykonuje, o funkcjach, jakie spełnia. Gdyby myśli dziecka nie miały podstawy nominatywnej, czyli gdyby nie umiało ono adekwatnie nazywać przedmiotów, które spostrzega, to nie mogłoby ich umieścić w swoim słowniku ${ }^{42}$. Amelia Dziurda-Multan dodaje, iż „dzieci najpierw wyodrębniają w przedmiotach cechy niezbędne do wykonania działań praktycznych i wówczas tworzą się u nich pojęcia przedmiotów codziennego użytku" 43 .

Wnioski dotyczące umiejętności tworzenia konstrukcji słowotwórczych przez badane dzieci/młodzież z niepełnosprawnością intelektualną w stopniu umiarkowanym:

Dzieci/młodzież dobrze sobie radzą z kodowaniem (tworzeniem, ekspresją) niektórych nazw narzędzi, por. budzik $(6,1 ; 15,6$; $17,11 ; 19,1 ; 19,6)^{44}$, drukarka $(17,11 ; 19,1 ; 19,6)$, dźwig $(8,11 ; 15,6 ; 19,1)$, grzejnik $(8,11 ; 17,11 ; 19,1 ; 19,6)$, gwizdek $(15,6 ; 17,11 ; 19,1)$, koparka $(6,1 ; 19,1 ; 19,6)$, lejek $(15,6 ; 17,11 ; 19,6)$, lokówka $(15,6 ; 17,11 ; 19,1 ;$ $19,6)$, odkurzacz $(6,1 ; 8,11 ; 15,6 ; 17,11 ; 19,6)$, skakanka $(6,1 ; 8,11 ; 15,6$; $17,11 ; 19,1 ; 19,6)$, spinacz (do bielizny) $(8,11 ; 15,6 ; 17,11)$, spinacz (biurowy) $(15,6)$, zapałka $(15,6 ; 17,11 ; 19,1)$, trochę słabiej z nazwami gaśnica $(17,11 ; 19,6)$, suszarka $(6,1 ; 19,1)$ wycieraczka (do butów) $(17,11$; $19,6)$, zapalniczka $(15,6 ; 17,11)$ oraz krajalnica $(19,6)$, pokrywka $(19,1)$, śrubokręt $(17,11)$ czy trzepaczka $(17,11)$.

Świadczy to o tym, że większość dzieci częściej wykorzystała w odpowiedziach zasadę przejrzystości znaczenia, używając formantów, które zna, mało tego, wybierając jedne z formantów najbardziej produktywnych $\mathrm{w}$ kategorii nazw narzędzi, tj. $-a c z,-a k$, -aczka, -arka, -nik.

Poza tym badani w odniesieniu do powyższych nazw narzędzi albo nie nazwali desygnatu w ogóle, por. brak nazwy dla: drukarka

42 S. Szuman, Rozwój treści słownika dzieci. Zagadnienie i niektóre wyniki badań, [w:] O rozwoju języka i myślenia dziecka, red. S. Szuman, PWN, Warszawa 1968, s. 10-11.

43 A. Dziurda-Multan, op. cit., s. 19.

${ }^{44} \mathrm{~W}$ nawiasach podaję wiek badanego/badanych w latach i miesiącach. 
$(8,11)$, dźwig $(19,6)$, gaśnica $(8,11)$, gwizdek $(19,6)$, krajalnica $(6,1 ; 8,11)$, lokówka $(8,11)$, przykrywka $(8,11)$, spinacz $(19,6)$, śrubokręt $(19,1)$, trzepaczka $(6,1 ; 19,1 ; 19,6)$, wycieraczka (do szyb) $(8,11)$, zapatka $(8,11)$, albo podali formacje zbudowane niepoprawnie, tworząc m.in. neologizmy słowotwórcze. Te ostatnie według jednych badaczy świadczą o kreatywności dziecka, a według innych - o niedojrzałości jego mowy. „Być może - jak pisze Agnieszka Wątorek - neologizmy pojawiają się tam, gdzie kończy się czyjaś wiedza i związane z nią słownictwo, aby dać ujście potrzebie werbalizacji myśli, która bywa silniejsza niż lęk przez popełnieniem błędu językowego"45. Wśród niepoprawnie utworzonych form znalazły się: a) konstrukcje utworzone niewłaściwymi formantami, ale typowymi dla omawianej kategorii słowotwórczej, por. gwizdak 'gwizdek' $(6,1)$, lejak 'lejek' $(19,1)$, odkurzak $(19,1)$; b) konstrukcje utworzone niewłaściwymi formantami, nietypowymi dla tej kategorii, por. gaśninka 'gaśnica' $(19,1)$, grzejka 'grzejnik' $(6,1)$, kopara $(17,11)$, krajniczka, krojonka 'krajalnica' $(17,11)$, krajanka 'krajalnica' $(19,1)$, pokrywa46 'przykrywka' $(19,6)$, spinka 'spinacz (do bielizny)' $(6,1 ; 19,1 ; 19,6)$, spinka 'spinacz (biurowy)' $(6,1 ; 8,11 ; 19,1)$, suszar 'suszarka' $(8,11)$, wycieranka 'wycieraczka (do butów)" (19,1), zapała 'zapałka' $(6,1)$, zapałkarka 'zapał$\mathrm{ka}^{\prime}(19,6)$.

Użycie przez dzieci/młodzież formantów -ka, -anka, -niczka, -ara itp., które nie są typowe dla kategorii nazw narzędzi, oznaczać może to, że dzieci te znają formanty, znają zasady ich użycia, natomiast nie są im znane znaczenia formantów.

Bardzo często zamiast nazwy narzędzia badani $\mathrm{z}$ niepełnosprawnością intelektualną $\mathrm{w}$ stopniu umiarkowanym podawali nazwy czynności wykonywanych z pomocą tych narzędzi/przez te narzędzia/urządzenia, por. drukuje 'drukarka' $(15,6)$, grzeje 'grzejnik' $(15,6)$, kopie 'koparka' $(15,6)$, kroi chlebek 'krajalnica' $(8,11)$, suszy 'suszarka' $(15,6)$, śrubki wkręca 'śrubokręt' $(15,6)$, trzepie się 'trze-

45 A. Wątorek, op. cit., s. 109.

46 Słowniki języka polskiego dopuszczają nazwę pokrywka obok powszechniejszej przykrywka. 
paczka' $(15,6)$, wyciera się 'wycieraczka (do butów)' $(15,6)$, wyciera 'wycieraczka (do butów, do szyb)' $(6,1)$, wycieramy buty $(15,6)$, sporadycznie nazwy wytworów czynności, por. druki 'drukarka' $(6,1)$, loczki 'lokówka' (6,1). W przypadku jednego dziecka odpowiedzi czasownikowe miały charakter echolaliczny, por. kopie 'koparka' $(8,11)$, leje 'lejek' $(8,11)$, trzepie 'trzepaczka' $(8,11)$.

Poza wymienionymi nazwami narzędzi dzieci/młodzież tworzyły(-a) derywaty: a) oparte na innych podstawach słowotwórczych, por. podnośnik 'dźwig' $(17,11)$; b) oparte na podstawie z uciętym nagłosem, por. szarka 'suszarka' $(17,11)$.

Parokrotnie pojawiły się odpowiedzi utworzone przez dzieci/młodzież na drodze asocjacji, skojarzeń, por. dywan 'wycieraczka (do butów)' (8,11), ogień 'gaśnica' $(6,1)$, patelnia 'przykrywka' $(15,6)$, do patelni 'przykrywka' $(6,1)$, szpilka 'spinacz (biurowy)' $(17,11)$, szyba 'wycieraczka (do szyb)' $(19,6)$, śrubka 'śrubokręt' $(6,1)$, śrubek 'śrubokręt' (8,11; 19,6), zegar cyk, cyk 'budzik' (8,11), od włosa 'suszarka' $(19,6)$.

Niekiedy skojarzenia były bardzo odległe, por. gas 'gaśnica' $(15,6)$ (chociaż tu może formant zerowy), lew 'lejek' $(6,1)$ (tu może z wlew, wlewac), pokrętka 'przykrywka' $(17,11)$.

Nieco większe problemy pojawiły się przy nazwach takich desygnatów, jak: cedzak, otwieracz czy trzepaczka 'narzędzie, zwykle druciane, używane w gospodarstwie domowym do ubijania białka jaj'. Badane dzieci/młodzież zwykle znają te przedmioty, wiedzą do czego służą (w trakcie badania pokazywały czynności, które się przy ich pomocy wykonuje), ale albo nie potrafią ich nazwać, por. brak nazwy dla: cedzak $(6,1 ; 19,6)$, otwieracz $(8,11)$, albo podają formacje zbudowane niepoprawnie, tj. a) z pomocą niewłaściwych formantów, ale typowych dla omawianej kategorii słowotwórczej, por. cedzarka 'cedzak' $(17,11)$; b) z pomocą niewłaściwych formantów, nietypowych dla tej kategorii, por. cedzanka 'cedzak' $(19,1)$, otwieranie 'otwieracz' $(17,11)$, otwórka 'otwieracz' $(19,1)$, albo oparte na innych podstawach słowotwórczych i przy pomocy nietypowych formantów, por. ubijanka 'trzepaczka (do jaj)' $(19,1)$. 
Również w przypadku tych nazw niektórzy badani podali nazwy czynności wykonywanych z pomocą tych narzędzi/przez te narzędzia/urządzenia, por. otwiera 'otwieracz' $(6,1 ; 19,6)$.

Jedno z dzieci utworzyło nazwę od złej podstawy słowotwórczej, ale użyło formantu typowego dla nazw narzędzi, por. odkrywacz 'otwieracz' $(15,6)$.

$\mathrm{Na}$ drodze asocjacji, skojarzeń powstała forma obiad 'cedzak' $(15,6)$.

Wnioski dotyczące umiejętności tworzenia konstrukcji słowotwórczych przez badane dzieci/młodzież z niepełnosprawnością intelektualną w stopniu znacznym:

Badani $\mathrm{z}$ niepełnosprawnością intelektualną w stopniu znacznym istotnie różnią się od tych $\mathrm{z}$ niepełnosprawnością $\mathrm{w}$ stopniu umiarkowanym. Nie znali i nie podali oni wielu nazw, por. brak odpowiedzi dla: budzik $(9,6)$, cedzak $(9,6)$, dźwig $(9,6)$, gaśnica $(9,6)$, grzejnik $(9,6)$, gwizdek $(9,6)$, lejek $(9,6 ; 15,2)$, lokówka $(9,6)$, otwieracz $(15,2)$, przykrywka $(15,2)$, skakanka $(9,6)$, spinacz $(9,6 ; 15,2)$, suszarka $(9,6)$, śrubokręt $(15,2)$, trzepaczka $(9,6 ; 15,2)$, wycieraczka $(9,6)$, zapałka $(9,6 ; 15,2)$.

Poza poprawnie utworzonymi derywatami, por. drukarka $(15,2)$, odkurzacz $(9,6)$ osoby ze znaczną niepełnosprawnością intelektualną przytoczyły: a) formacje oparte na prawidłowych podstawach słowotwórczych, ale $z$ nieprawidłowymi formantami, chociaż typowymi dla kategorii nazw narzędzi, por. gwizdak 'gwizdek' $(9,6)$, suszacz „suszarka' $(15,2)$; b) formacje oparte na prawidłowych podstawach słowotwórczych, ale $z$ nieprawidłowymi formantami, nietypowymi dla kategorii nazw narzędzi, por. kopara 'koparka' $(15,2)$, krajanie 'krajalnica' $(15,2)$, odkurzan 'odkurzacz' $(15,2)$, skakanie 'skakanka’ (15,2), spina, -y (l.mn.) 'spinacz (do bielizny)’ (15,2), suszawka 'suszarka' $(9,6)$.

Podobnie jak w przypadku osób z niepełnosprawnością w stopniu umiarkowanym i tu zdarzyło się że jeden $z$ badanych podał nie nazwy narzędzi, a nazwy czynności wykonywanych z pomocą tych narzędzi/przez te narzędzia/urządzenia, por. gasi 'gaśnica' $(15,2)$, gwizda 'gwizdek' $(15,2)$, wyciera 'wycieraczka (do szyb)' $(15,2)$. 
Kilka nazw podanych przez respondentów powstało $\mathrm{w}$ wyniku asocjacji, skojarzeń, zarówno bezpośrednich, por. auto 'dźwig' $(15,2)$, dzwonek 'budzik' $(15,2)$, garnek 'przykrywka' $(9,6)$, misa 'cedzak' $(15,2)$, jak i pośrednich, por. kredka 'drukarka' $(9,6)$ (być może poprzez skojarzenie wydruków malowanek), szuflada 'śrubokręt' $(9,6)$ (niekiedy trzyma się śrubokręty w tym miejscu), być może też rękaw 'budzik' $(9,6)$ (wskazówki niektórych zegarków dla dzieci mają kształt rękawów/rąk pajaca).

\section{Podsumowanie}

Trudno przy tak małych liczebnie grupach badawczych wyciągać jakieś szczegółowe wnioski. Sformułowanie szczegółowych wniosków może nastąpić dopiero wówczas, gdy zebrany zostanie reprezentatywny i bogaty materiał ilustrujący procesy akwizycji reguł słowotwórczych. Można pokusić się jednak o kilka ogólnych uwag:

1. Jeśli chodzi o kodowanie formacji słowotwórczych, jakimi są nazwy narzędzi, to dzieci/młodzież z niepełnosprawnością intelektualną $\mathrm{w}$ stopniu umiarkowanym całkiem nieźle sobie radzą, znacznie gorzej $\mathrm{w}$ badaniach ekspresji nazw narzędzi wypadają osoby z niepełnosprawnością intelektualną w stopniu znacznym.

2. Wnioski wypływające $\mathrm{z}$ powyższych badań mogą weryfikować tezy znane $\mathrm{z}$ literatury przedmiotu, że osoby z głębszą niepełnosprawnością intelektualną, a szczególnie ci ze znaczną, znają i posługują się tylko minimalnym zasobem słów.

3. Wyniki badań mogą wskazywać też na fakt, że akwizycja języka zależy nie tylko od ogólnego rozwoju dziecka, ale też od warunków, jakie zapewnia mu jego rodzina i najbliższe otoczenie $^{47}$. Czynnikami warunkującymi rozwój kompetencji ję-

47 J. Porayski-Pomsta, O rozwoju mowy dziecka. Dwa studia, Wyd. Dom Wydawniczy „Elipsa”, Warszawa 2015, s. 48. 
zykowej u dzieci z niepełnosprawnością intelektualną są m.in. sytuacje i wydarzenia/doświadczenia życiowe ${ }^{48}$. Mogą świadczyć o tym chociażby przykłady typu drukarka, odkurzacz, a nawet gwizdak, kopara, krajanie, odkurzan, suszacz, suszawka itp. zanotowane u osób ze znaczną niepełnosprawnością intelektualną.

\section{Bibliografia}

Aitchison J., Ziarna mowy, PIW, Warszawa 2002.

Błeszyński J.J., Niepetnosprawność intelektualna. Mowa - język - komunikacja. Czy iloraz inteligencji wyjaśnia wszystko?, Harmonia Universalis, Gdańsk 2013.

Bogdanowicz M., Psychologia kliniczna dziecka w wieku przedszkolnym, WSiP, Warszawa 1985.

Borowiec H., Kategorie interpretowania rzeczywistości w języku dzieci, [w:] Język - interakcja - zaburzenia mowy, Metodologia badań, red. T. Woźniak, A. Domagała, Wydawnictwo Uniwersytetu Marii Curie-Skłodowskiej, Lublin 2007.

Chmura-Klekotowa M., Neologizmy stowotwórcze w mowie dzieci, „Prace Filologiczne” 1971, nr 21.

Cierpiałkowska L., Psychopatologia, Wydawnictwo Naukowe Scholar, Warszawa 2007.

Dokulil M., Teoria derywacji, tłum. A. Bluszcz, J. Stachanowski, Ossolineum, Wrocław 1979.

Dołęga Z., Promowanie rozwoju mowy w okresie dzieciństwa - prawidłowości rozwoju, prognozowanie i profilaktyka, Wydawnictwo Uniwersytetu Śląskiego, Katowice 2003.

Doroszewski W., Kategorie stowotwórcze, „Sprawozdania z posiedzeń Towarzystwa Naukowego Warszawskiego", Wydz. I, 1946, t. XXXIX.

Dziurda-Multan A., Dziecięce sposoby tworzenia nazw, Wydawnictwo Katolickiego Uniwersytetu Lubelskiego, Lublin 2008.

Gałkowski T., Dzieci specjalnej troski. Psychologiczne podstawy rehabilitacji dzieci opóźnionych umystowo, Wiedza Powszechna, Warszawa 1979.

Giermakowska A., Ocena kompetencji stowotwórczej uczniów z trudnościami w czytaniu i pisaniu na poziomie edukacji wczesnoszkolnej, „Szkoła Specjalna” 2012, z. 5.

${ }^{48} \mathrm{Z}$. Dołęga, Promowanie rozwoju mowy w okresie dziecinstwa - prawidłowości rozwoju, prognozowanie i profilaktyka, Wydawnictwo Uniwersytetu Śląskiego, Katowice 2003, s. 30. 
Głodkowska J., Pomóżmy dziecku z upośledzeniem umysłowym doświadczać przestrzeni. Orientacja przestrzenna w teorii, diagnozie i rozwoju dziecka, WSPS, Warszawa 2000.

Grabias S., Jezzyk, poznanie, interakcja, [w:] Jezzyk. Interakcja. Zaburzenia mowy. Metodologia badań, red. T. Woźniak, A. Domagała, Wydawnictwo Uniwersytetu Marii Curie-Skłodowskiej, Lublin 2007.

Griffer M.R., Language and children with intellectual disorders, [w:] An introduction to children with language disorders, red. V.A. Reed, M.A. Pearson, wyd. IV, Boston 2012.

Grzegorczykowa R., Zarys stowotwórstwa polskiego. Słowotwórstwo opisowe, PWN, Warszawa 1982.

Grzegorczykowa R., Szymanek B., Kategorie słowotwórcze w perspektywie kognitywnej, [w:] Wspótczesny język polski, red. J. Bartmiński, Wydawnictwo Uniwersytetu Marii Curie-Skłodowskiej, Lublin 2001.

Kaczmarek L., Nasze dziecko uczy się mowy, Wydawnictwo Lubelskie, Lublin 1966.

Kaczorowska-Bray K., Zaburzenia komunikacji językowej w grupie osób z niepetnosprawnościa intelektualna, [w:] Diagnoza i terapia logopedyczna osób z niepetnosprawnościa intelektualna, red. J.J. Błeszyński, K. Kaczorowska-Bray, Harmonia Universalis, Gdańsk 2012.

Kaczorowska-Bray K., Kompetencja i sprawność językowa dzieci z niepetnosprawnościq intelektualna w stopniu znacznym, umiarkowanym i lekkim, Wydawnictwo Uniwersytetu Gdańskiego, Gdańsk 2017.

Kostrzewski J., Różnice profilu inteligencji, niektórych uzdolnień oraz w cechach motoryczności dzieci umysłowo upośledzonych i normalnych, [w:] Z zagadnień psychologii dziecka umystowo upośledzonego. Materiały pomocnicze do psychologii upośledzonych umysłowo, red. J. Kostrzewski, t. 1, Wydawnictwo WSPS im. M. Grzegorzewskiej, Warszawa 1978.

Kostrzewski J., Podstawy wspótczesnej diagnostyki psychologiczno-klinicznej niedorozwoju umysłowego u dzieci, [w:] Z zagadnień psychologii dziecka umysłowo upośledzonego. Materiały pomocnicze do psychologii upośledzonych umysłowo, red. J. Kostrzewski, t. 1, Wydawnictwo WSPS im. M. Grzegorzewskiej, Warszawa 1978.

Kostrzewski J., Charakterystyka osób upośledzonych umysłowo, [w:] Upośledzenie umystowe - Pedagogika, red. K. Kirejczyk, PWN, Warszawa 1981.

Kościelak R., Psychologiczne podstawy rewalidacji upośledzonych umystowo, PWN, Warszawa 1989.

Kudłacik E., Poziom funkcjonowania dzieci głębiej upośledzonych umysłowo w wieku przedszkolnym w zakresie porozumiewania się oraz umiejętności stuchowo językowych i wzrokowoprzestrzennych, [w:] Komunikacja - mowa - język w diagnozie $i$ terapii zaburzeń rozwoju u dzieci i młodzieży niepetnosprawnej, red. E. Minczakiewicz, Wydawnictwo Naukowe AP, Kraków 2002.

Kurcz I., Jezzyk a psychologia, WSiP, Warszawa 1992. 
Kurcz I., Psychologia języka i komunikacji, Wydawnictwo Naukowe „Scholar” Warszawa 2000.

Łuczyński E., Fleksja języka polskiego z punktu widzenia ontogenezy mowy, „Biuletyn Polskiego Towarzystwa Językoznawczego" 2002, t. 58.

Michalik M., Kompetencja składniowa w normie i zaburzeniach. Ujęcie integrujace, Wydawnictwo Naukowe Uniwersytetu Pedagogicznego, Kraków 2011.

Mnich M., Sprawność językowa dzieci w wieku wczesnoszkolnym, Oficyna Wydawnicza "Impuls", Kraków 2002.

Muzyka E., Sposoby interpretowania konstrukcji słowotwórczych przez dzieci niestyszące, „Logopedia” 2007, t. 36.

Muzyka-Furtak E., Konstrukcje słowotwórcze w świadomości językowej dzieci niestyszacych, Wydawnictwo Uniwersytetu Marii Curie-Skłodowskiej, Lublin 2010.

Muzyka-Furtak E., Kwestionariusz słowotwórczy w ocenie kompetencji językowej dzieci $z$ zaburzeniem stuchu, [w:] Metody $i$ narzędzia diagnostyczne w logopedii, red. M. Kurowska, Wolańska E., Dom Wydawniczy Elipsa, Warszawa 2015.

Muzyka-Furtak E., Twórczość wyrazowa dzieci 7-letnich, "Logopedia” 2011, t. 39/40.

Porayski-Pomsta J., O rozwoju mowy dziecka. Dwa studia, Dom Wydawniczy „Elipsa”, Warszawa 2015.

Rozwadowski J., O zjawiskach i rozwoju języka. 9. O dwuczłonowości wyrazów, „Język Polski" 1921, z. 6.

Stawinoga R., Twórczość językowa dziecka w teorii i praktyce edukacyjnej, Wydawnictwo Uniwersytetu Marii Curie-Skłodowskiej, Lublin 2007.

Szuman S., Rozwój treści słownika dzieci. Zagadnienie i niektóre wyniki badań, [w:] O rozwoju języka i myślenia dziecka, red. S. Szuman, PWN, Warszawa 1968.

Tarkowski Z., Mowa osób upośledzonych umysłowo i jej zaburzenia, [w:] Podstawy neurologopedii. Podręcznik akademicki, red. T. Galkowski, E. Szeląg, G. Jastrzębowska, Uniwersytet Opolski, Opole 2005.

Wątorek A., Kompetencja językowa uczniów z lekką niepetnosprawnościa intelektualna, Nomos, Kraków 2014.

Zarębina M., Kształtowanie się systemu językowego dziecka, Ossolineum, Wrocław 1965. Zarębina M., Język polski w rozwoju jednostki. Analiza tekstów dzieci do wieku szkolnego. Rozwój semantyczny języka dziecka, Wydawnictwo Naukowe WSP, Kraków 1980. 